\title{
THE ACADEMIC PRACTICE OF COMPARATIVE LITERATURE IN ASSAM: THE ROLE OF DIBRUGARH AND GAUHATI UNIVERSITY \\ Pallabika Sarmah ${ }^{1}$, Samutjal Saikia $^{2 *}$
}

${ }^{1}$ Assistant Professor (pp), Department of Assamese, Cotton University, Assam, India, ${ }^{2}$ Research Scholar, Department of Assamese, Dibrugarh University, Assam, India.

Email: *samutjalnlc@gmail.com

\section{Article History: Received on $24^{\text {th }}$ August 2019, Revised on $25^{\text {th }}$ September 2019, Published on $30^{\text {th }}$ October 2019}

\begin{abstract}
Purpose: This paper aims to present a picture of the evolution, present condition and the prospect of Comparative Literature in the academic world of Assam by mainly giving example of the numerous works done on the discipline in Assam, the syllabus of Dibrugarh and Gauhati University and the research works and projects done in these respective universities.
\end{abstract}

Methodology: The research methods mainly used in this study are analytical and survey methods. The necessary materials are collected from library and used, with proper observation and analysis, to justify the proposed ideas.

Main Findings: This paper, with clear data, seems to cast light on the trajectory of Comparative Literature in Assam, especially of the present situation and with the observation of these data, an effort is made to get a view of its prospect.

Application: Besides getting acquainted with the evolution of the discipline of Comparative Literature in Assam, this paper seems to be beneficial in comprehending the required adaptation and changes for the discipline in the current situation.

Novelty/Originality: The significance of this paper lies in its effort to give a critical look at the discipline from its beginning to the present situation and most importantly, the discussion of the lacks and faults of its practice and of various steps for the development of the discipline in the state will be very relevant and instrumental in the context of Assam.

Keywords: Academic Practice, Comparative Literature, Assam, School, University, Syllabus.

\section{INTRODUCTION}

The discussion about the theory of Comparative Literature was started in the mid $20^{\text {th }}$ century. The person who paved the way for the academic study of the subject is Jageswar Sharma who in the journal of the Assam Sahitya Sabha of 1977, wrote an essay titled Tulanamulak Sahitya (Comparative Literature) where he discusses the theory of Comparative Literature and shows its importance. Another major development comes in the hands of a scholar named Prafulla kataki who wrote the first book about Comparative Literature titled Tulanmulok Sahitya (Comparative Literature) in the year 1989 (Bezborah, 2009). It is noteworthy to mention that it is Prafulla kataki who is considered, as supported by many books, the first person to bring out the subject of Comparative Literature. But it is Jogeswar Sharma who first brought the subject to the realm of literary discussion eleven years before Prafulla kataki. Nirajona Mahanta Bezborah in her book Tulonamulok Sahitya Aru Sahityik Gobekhona (Comparative Literature and Literary Research), published in 1994, writes "Comparative Literature in Assam is in a very nascent condition. In Assamese language, the subject had its beginning in Dr. Prafulla Kataki's book Tulanamulok Sahitya (1989)" (Bezborah,1999). But we would like to inform, along with Nirajona, all the learned society of Assam that instead of Prafulla kataki's book, it is the article titled Tulanamulak Sahitya by Jogeswar Sharma written 11 years before Prafulla's book is the first essay written on Comparative Literature. But, unfortunately, the name of Jogeswar Sharma cannot be seen in the books pertaining to Comparative Literature written till today.

In the second half of the twentieth century, there were very few literary works produced that dealt with Comparative literature and only a handful of people were involved in bringing the subject into the academic world among which Jogeshwar Sharma is the first who gave a clear idea about the subject. He published an article in the first volume of 'Asom Sahitya Sabha Patrika' of the $14^{\text {th }}$ year in 1977 (Sharma,1977) where he explains, in a very lucid manner, the nature of Comparative literature. In the article, he gives a brief description of the idea, purpose, scope, and discussion of Comparative Literature done in Western countries (Saikia, 2018; Bezborah, 2019). The idea that had its beginning in Sharma's article was strongly established by Prafulla Kataki in his book Tulonamulok Sahitya where he gives an idea about the definition, significance, scope, purpose, usefulness of Comparative Literature, World Literature, etc. Gradually, Comparative Literature drew the attention of the learned society and they started considering it as a subject of profound discussion. In the year 1992, a seminar was held at Dibrugarh University on Comparative Literature were eminent scholars like Mahendra Borah, Amoresh Dutta, etc. put forwarded a very good discussion on Comparative Literature (Buzarboruah 2013). By realizing the significance of the subject, the Assamese Department of Dibrugarh University, established in 1965, included three comparative Indian literature papers in its syllabus. But to have a clear and broad understanding of the subject, there was a lack of books apart from Prafulla Kataki's book. In order to make the subject clearer, other writers also tried to write books on the topic. For instance, Nirajana Mahanta Bezborah published a book titled Tulonamulak Sahitya 
and Sahityik Gobekhona (Comparative Literature and Literary Research ) where she discusses the nature of Comparative Literature, translation, the unity among the Indian literature, comparative research, folklore research, etc. There are some other books containing broad discussion of Comparative Literature written by this writer such as Tulanamulak Sahitya: Sidhanta and Prayug (Comparative Literature: Decision and Application), Tulonamulok Sahitya (Comparative Indian Literature), Patobhumikat Tulonamulok Sahitya (Comparative Literature in Context), etc. Later on, other eminent scholars also wrote articles pertaining to comparative literature and among them; Nagen Saikia's name is worth mentioning. He wrote an article titled "Tulonamulok Sahitya" (Saikia, 2011) (Comparative Literature) in the book Sahitya- Badboisitra. The name of the works of other writers are mentioned below: (Nath, 2017)

\begin{tabular}{ll}
\hline \multicolumn{1}{c}{ Writers } & Books \\
\hline Karabi Deka Hazarika & $\begin{array}{l}\text { Tulonamulok Sahitya Aru Anubad Kala (Comparative } \\
\text { Literature And the Art of (Translation) 2003 }\end{array}$ \\
\hline Dilip Borah & Tulonamulok Sahitya (Comparative Literature) 2003 \\
\hline Prafulla Kumar Nath & $\begin{array}{l}\text { Tulonamulok Bharatiya Sahitya : Bisar Aru } \\
\text { Bishlekhan (Comparative Indian Literature: Judgement } \\
\text { And Analysis 2005) and Tulanamulak Sahitya: Tattwa } \\
\text { and Prayug (Comparative Literary Theory and } \\
\text { Application) 2015 }\end{array}$ \\
\hline Karabi Deka Hazarika & $\begin{array}{l}\text { Tulanamulak Sahitya Tattwa (Comparative Literary } \\
\text { Theory), 2013 }\end{array}$ \\
\hline
\end{tabular}

\section{LITERATURE REVIEW}

Various articles and books are published in Assam on comparative studies. Some of the comparative studies that had been done before includes - Prafulla Kataki's 'Tulanamulak Sahitya aru Anubad Bisar'; Nirajana Mahanta Bezborah's 'Tulanamulak Bharitya Sahitya', Tulonamulok Sahitya Aru Sahityik Gobekhona', 'Anubad Kala'; Karabi Deka Hazarika's 'Tulanamulak Sahitya aru Anubad Kala'; Dilip Bora's 'Tulanamulak Sahitya'; Pallavi Deka Buzarboruah's 'Tulanamulak Sahityatattwa'; Dhrubajyoti Nath's 'Tulanamulak Sahitya - Patabhumikat Asom'. These books and articles were studied for preparing this paper.

\section{METHODOLOGY}

Analytical and descriptive methods are mainly used in this paper. Critical methods have been used in this study to analyze the collected data.

\section{RESULTS/DISCUSSION}

\section{COMPARATIVE LITERATURE IN THE SYLLABUS OF DIBRUGARH UNIVERSITY}

In the year 1992, Dibrugarh University has included Comparative Literature as a part of the M.A. syllabus of the Assamese department and this step adopted by Dibrugarh University, in the Academic world, was the first initiative in the entire North- East. In the three alternative papers of the abovementioned syllabus, Comparative literature and Comparative Indian Literature were included (Bezborah, 1999). In the first paper titled "Comparative Literature", the significant aspects pertaining to the concept, significance, history, and translation in Comparative literature, etc. are briefly discussed. Moreover, Western literature, Assamese literature and other regional literary texts of India were included for comparative analysis. Those literary texts were some selected poems of William Wordsworth, P.B. Shelley, S.T. Coleridge and John Keats, Sophocles' Oedipus Rex and Albert Camus' The Outsider. The first part of the Second paper titled 'Comparative Indian Literature" contains the Bengali Literature, Assamese Literature, and selected writings of Kritibash and Bidyapati, Jagannath Das and Tulsidas from Hindi literature. On the other hand, the second part includes modern poetry from Bengali. Assamese, Odiya and Hindi literature for comparative study. The prescribed poems were Balaka by Rabindranath Tagore, Uttarayan by Baikuntha Nath Patnaik, and Dipsikha by Mahadevi Varma. In the first part of the third paper, there is the inclusion of drama from the Modern Assamese, Bengali, Odia and Hindi literature such as Himendranath Barthakur's Bagh, Badal Sarkar's Abong Indrajit, Manuranjan Das' Aranyar Fasal and Mohon Rakesh's Akhar Ka Ek Din, etc. The prescribed text of the second part is taken from the prose literature of modern Assamese, Bengali, Odia and Hindi languages such as Koka Deotar Har by Nabakanta Barua, Pother Panchali by Bibhuti Bhushan Bandopadhyay, Matir Monus by Kalindi Charan Panigrahi and Godan by Premchand. The university, by following this pattern, added some other texts in the syllabus of M.A. (distance), and B.A. syllabus of Assamese Department. In the subsequent time, the amended syllabus of Dibrugarh University replaced the earlier European literature with some famous writers from other parts of the world such as Kalidasa from Sanskrit, Anton Chekhov from Russia, O Henry from the USA, Maupassant from France and Lorca from Spanish and thereby enlarged the scope of studying the field of World Literature. Similarly, in the amended syllabus of Comparative Indian Literature includes Gujarati (Dhiruben Patel) and Marathi (Narayan Pendse) Literature. In the current M.A. syllabus of the paper Comparative Literature, some of the important included aspects are: history, 
definition, fields, school, literary terms, methods, the concept of Indian literature and history, the comparative study of Hindi-Bengali-Malayalam literature in the context of India, etc.

The purpose behind the inclusion of Comparative Literature and Comparative Indian Literature in the syllabus of Dibrugarh University is:

To acquaint the students with the concepts and preliminary theory of Comparative Literature and through the prescribed texts, to give an idea of the culture of a nation. It also aims at acquainting the students with the different subject matters, types and historical similarities reflected in different literatures. Moreover, making the students aware of the different characteristics of different ages is another intention of this initiative. It is worth mentioning that, in the entire syllabus there is an emphasis on studying Assamese literature from comparative perspective. Rather than approaching Assamese literature as a different entity, this paper aims at approaching it as a branch or part of the broad umbrella of Indian literature.

\section{COMPARATIVE LITERATURE IN THE SYLLABUS OF GAUHATI UNIVERSITY:}

Gauhati University included Comparative Literature in the M.A. syllabus of the Assamese Department in the year 2001 and later on also included it in its B.A. syllabus. (Bora Tanuja, \& Nath, Dhrubajyoti, 2017) In the M.A. level, a paper on Comparative Indian Literature and another on translation were included. In the Comparative Indian Literature paper, the theory and history of Comparative Literature were included. In the paper, the Hindi text of Maithili Sharan Gupt and Sumitrananda Pant, Bengali poetry of Rabindranath Tagore and Jibanananda Das, Guleri by Chandradhar Sharma and the short stories of Usha Priyamwada such as Usne Kaha Tha and Wapsi, the Bengali short stories by Sarat Chandra Chattopadyay and Tagore such as Obhagir Swarga and Kawbulliwalla, Hindi novel Nirmala by Premchand and Pather Panchali by Bibhutubhushan Bandyoupadyay etc. are included. On the other hand, the concerned topics of the translation paper are different theories and standpoints pertaining to translation, different types of translation, etc. The paper made from the perspective of Comparative Literature includes the study and analysis of different translated texts from Hindi, Bengali and English Literature. By following the pattern of the M.A. syllabus, Comparative Literature and its various theories and history are also included in the syllabus of distance education. Some representative texts from Bengali and Hindi Literature are also included for discussion. The B.A. syllabus of Gauhati University includes the introduction to Indian Literature and some Modern Literary text from the regional literature of India such as Tagore's Postmaster, Premchand's Kaffan and Manik Bandopadhyay's Padma Nadir Majhi and Phanishwar Nath Renu's, Maila Anchal. Moreover the idea, definition, field, text, and types different schools of Comparative Literature are also added in the syllabus.

\section{THE M.PHIL RESEARCH WORKS DONE IN DIBRUGARH UNIVERSITY}

\begin{tabular}{lll}
\hline Researcher's Name & Department/Year & Title of the Research Work \\
\hline Asyut Saikia & Assamese/ 1998 & $\begin{array}{l}\text { Rojonikanta Bordoloi's Monumati } \\
\text { Bankim Chandra Chatyupadya's } \\
\text { Durgekhnandini: A Comparative } \\
\text { Study }\end{array}$ \\
\hline Rita Chetia & Assamese/2001 & $\begin{array}{l}\text { A Comparative Study of } \\
\text { Rabindranath Tagore's Raja and } \\
\text { Jyotiprasad Agarwala's Nimati Koina }\end{array}$ \\
\hline Palash Gogoi & & Naliniwala Devi's Sandhyar Sur and \\
& Assamese/2006 & $\begin{array}{l}\text { Mahadevi Barma's Dipshikha: A } \\
\text { Comparative Study }\end{array}$ \\
\hline Mridula Baruah & & 2008 The Generation Gap in Godan \\
& Assamese/2008 &
\end{tabular}

\section{PH. D RESEARCH WORKS}

\begin{tabular}{|c|c|c|}
\hline Researcher's Name & Department/ Year & Title of the Research Work \\
\hline Pallavi Deka Buzarboruah & Assamese/2000 & $\begin{array}{l}\text { The Poetic Philosophy of } \\
\text { Rabindranath Tagore And the Poetry } \\
\text { of his Followers: A Comparative } \\
\text { Study And the Poetry of his } \\
\text { Followers: A Comparative }\end{array}$ \\
\hline Jumi Baruah & Assamese/2001 & $\begin{array}{l}\text { Comparative Study Between } \\
\text { Assamese and Bengali Folklore }\end{array}$ \\
\hline Anju Bora & Assamese/2001 & $\begin{array}{l}\text { Comparative Study Between the } \\
\text { Novels of Bibhuti Bhushan and Siyad } \\
\text { Abdul Malik }\end{array}$ \\
\hline Mahendra Narayan Choudhry & Assamese/ 2003 & $\begin{array}{l}\text { Comparative Study Between Pather } \\
\text { Panchali and Jibanar Batot }\end{array}$ \\
\hline
\end{tabular}


Folktales

\section{RESEARCH PROJECTS}

\begin{tabular}{lll}
\hline Researcher's Name & Department/ Year & Title of the Research Work \\
\hline Bashanata Kumar Sharma & Assamese/2003 & $\begin{array}{l}\text { Medieval English and Assamese } \\
\text { Religious Drama: A Comparative } \\
\text { Study }\end{array}$ \\
\hline Bashanata Kumar Sharma & Assamese/2003 & $\begin{array}{l}\text { Assessment of the Ideas and } \\
\text { nature of the poetry Of } \\
\text { Jibanananda Das and Nabakanta } \\
\end{array}$ \\
& & Baruah \\
\hline Karabi Deka Hazarika & Assamese/2006 & Beginning of Modernism in \\
& & Assamese and Bengali Poetry \\
\hline Joyanta Kumar Borah & Assamese/2008 & The Beginning Phase of the \\
& & Assamese and Bengali Prose \\
\end{tabular}

\section{SOME NOTABLE Ph.D. RESEARCH WORKS DONE UNDER GAUHATI UNIVERSITY}

\begin{tabular}{|c|c|c|}
\hline Researcher's Name & Department/ Year & Title of the Research Work \\
\hline Indira Goswami & Assamese/1973 & $\begin{array}{l}\text { A comparative Study of } \\
\text { Ramayana of Madhab Kandali } \\
\text { and Tulsidas }\end{array}$ \\
\hline Ananda Mohan Mokhopadhya & Modern Assamese Language/1974 & $\begin{array}{l}\text { A Comparative Study in } \\
\text { Eksaraniya Vaishnava and } \\
\text { Goudiya Vaishnava in Bengal }\end{array}$ \\
\hline Bani Bhattacharya & Modern Assamese Language/1978 & $\begin{array}{l}\text { A Comparative Study of Madhab } \\
\text { Kandali and Kritivasa }\end{array}$ \\
\hline Nirmali Das & Modern Assamese Language/1981 & $\begin{array}{l}\text { A Comparative Study of the } \\
\text { Devotional (Vaishnava) Lyrics of } \\
\text { Assam and Bengal }\end{array}$ \\
\hline Nirupama Nath & Bengali/1987 & $\begin{array}{l}\text { Historical Novels of Bankim } \\
\text { Chandra and Rameschandra : A } \\
\text { Comparative Study }\end{array}$ \\
\hline Swadhinata Mahanta & Hindi/1990 & $\begin{array}{l}\text { A Comparative Study of Dramas } \\
\text { of J.P Agarwala and Joy Sankar } \\
\text { Prasad }\end{array}$ \\
\hline Sumita Choudhry & Bengali/1996 & $\begin{array}{l}\text { A Comparative Study of } \\
\text { Autobiographies of Rasosundari } \\
\text { Devi (1810) and Nalinibana Devi } \\
\text { (1898) of Assam }\end{array}$ \\
\hline Beauty Mahanta & Hindi/1997 & $\begin{array}{l}\text { Surdas and Madhavadeva: A } \\
\text { Comparative Study with Special } \\
\text { Reference to Vatsalya Rasa } \\
\text { Revealed in their Literature }\end{array}$ \\
\hline Rekha Dhar & Bengali/1998 & $\begin{array}{l}\text { Bankim Chandra Chatterjee and } \\
\text { Lakshminath Bezboruah: A } \\
\text { Comparative Study of Their } \\
\text { Literary Works }\end{array}$ \\
\hline Anjali Kakati & Hindi/ 1998 & $\begin{array}{l}\text { Comparative Study of the Women } \\
\text { Characters of Assamese } \\
\text { Saptakanda Ramayana and } \\
\text { Ramcharitmanasa }\end{array}$ \\
\hline Bipul Chandra Kalita & folk culture $/ 2000$ & $\begin{array}{l}\text { A Comparative Study of } \\
\text { Assamese and Bhojpuri Oral } \\
\text { Songs }\end{array}$ \\
\hline
\end{tabular}




\section{A COMPARATIVE DISCUSSION BETWEEN ASSAMESE LITERARY WORKS AND LITERARY WORKS OF OTHER INDIAN LANGUAGE}

Besides being studied as an academic subject in Dibrugarh and Gauhati University, many books are written in the Assamese from Comparative standpoint. Many writings are published in journals and Research journal. The name of some of the books and articles studied in Comparative Literary discussion are mentioned below:

\section{BOOKS}

1. Rabindranath Tagore and Assamese Short Story- Parag Kumar Bhatacharya, Banlata, 1994

2. Assamese, Bengali, and Odiya Language: A Comparative Study- Dipti Phukan Patgiri, Banlata, 2004

3. Some Aspects of the Unity between Assamese and Odiya Culture- Jyotshna B Rauat, Bani Mandir, 2005

4. The poetry of Jibanananda Das and Nabakanta Baruah- Prahlad Kumar Baruah, Kiran Prakakhan, 2007

\section{ARTICLES}

\begin{tabular}{|c|c|c|}
\hline Practising Works & Writers & $\begin{array}{l}\text { Magazine/ Research Journal/ } \\
\text { Books }\end{array}$ \\
\hline $\begin{array}{l}\text { Medieval Assamese Dramas and Comparative } \\
\text { Dance Dramas of Other Parts of India }\end{array}$ & Maheswar Neog & $\begin{array}{l}\text { Journal of the University of } \\
\text { Gauhati, } 1995\end{array}$ \\
\hline Madhabdev and Surdas: A Comparative Discussion & Karabi Deka Hazarika & $\begin{array}{l}\text { Madhavdeva: Literature, Art } \\
\text { and Philosophy/1987 }\end{array}$ \\
\hline Poet Nabakanta Barua and Rabindra-Chetana & Pallavi Deka Buzarboruah & $\begin{array}{l}\text { Asom Sahitya Sabha Patrika, } \\
\text { Feb. } 2001\end{array}$ \\
\hline $\begin{array}{l}\text { Sita from the Utarakanda of Valmiki And } \\
\text { Sankardeva: A Comparative Study }\end{array}$ & Naba Kumar Handique & $\begin{array}{l}\text { The Ramayana Tradition of } \\
\text { North East India/2002 }\end{array}$ \\
\hline $\begin{array}{l}\text { Rabindranath and Assamese Poetry In the light of } \\
\text { the tradition of the Upanishad }\end{array}$ & Pallavi Deka Buzarboruah & Gariyoshi, May 2002 \\
\hline The Poetry of Parbatiprasad and Rabindranath & Pallavi Deka Buzarboruah & $\begin{array}{l}\text { Lyricist } 4 \text { Parvatiprashad: } \\
\text { Assessment Of Life and } \\
\text { Creativity, 2004 }\end{array}$ \\
\hline The Poetry of Bezboruah and Rabindranath & Pallavi Deka Buzarboruah & Gariyoshi, May, 2006 \\
\hline Aesthetics, Rabindranath and Assamese Poetry & Pallavi Deka Buzarboruah & Anves, Jan-Jun, 2006 \\
\hline $\begin{array}{l}\text { Rabindranath Romanticism and Assamese } \\
\text { Romantic Poetry }\end{array}$ & Pallavi Deka Buzarboruah & Gariyoshi, September,2008 \\
\hline Assamese Literature and Rabindra Philosophy & Pallavi Deka Buzarboruah & $\begin{array}{l}\text { Assamese } \\
\text { Characteristics and Context, } \\
\text { October, 2008 }\end{array}$ \\
\hline $\begin{array}{l}\text { Comparative Literature and Comparative Indian } \\
\text { Literature in Their Development }\end{array}$ & Pallavi Deka Buzarboruah & $\begin{array}{l}\text { Literature's Taste- Diversity, } \\
\text { Feb. } 2009\end{array}$ \\
\hline $\begin{array}{l}\text { The Distinguishing Nature of Comparative Indian } \\
\text { Literature and Some Promising Aspects of its } \\
\text { Development }\end{array}$ & Pallavi Deka Buzarboruah & Gariyoshi, July, 2009 \\
\hline $\begin{array}{l}\text { A Glance at Some Modern } \\
\text { Rabindranath and Tagore }\end{array}$ & allavi Deka Buzarboruah & Kesahun, February, 2010 \\
\hline $\begin{array}{l}\text { The Romantic Nature of Rabindranath and } \\
\text { Assamese Romanticism }\end{array}$ & allavi Deka Buzarboruah & shi, June and July, 2011 \\
\hline $\begin{array}{l}\text { The relevance of Rabindra- thought Literature In } \\
\text { Present Context }\end{array}$ & Pallavi Deka Buzarboruah & Kesahun, 2011-12 \\
\hline $\begin{array}{l}\text { The Development of the Schools of Comparative } \\
\text { Indian Literature: Possibilities and Literature }\end{array}$ & Pallavi Deka Buzarboruah & Prakakh, May, 2012 \\
\hline $\begin{array}{l}\text { Comparative Literature: An Approach to Indian } \\
\text { School }\end{array}$ & Pallavi Deka Buzarboruah & $\begin{array}{l}\text { International Journal of } \\
\text { Humanities and Social Science } \\
\text { Invention Oct,1014 }\end{array}$ \\
\hline
\end{tabular}

\section{A REVIEW}

Besides the two above mentioned universities in Assam, some other newly established universities like the Sankardeva and Assam Women University also have the subject of Comparative Literature in their syllabus. Even the syllabus of some autonomous colleges is seen including Comparative Literature in Master's Degree. But the systematic and academic study of Comparative Literature is not in an advanced position in Assam. The field of Comparative Literature is very broad and in this broad field, there cannot be seen enough practice in Assam. Despite being established as an academic subject or 
department in various institutions, there is an absence of its clear purpose, methodology and theoretical foundation till today. Some of the practices that are currently going on are:

1. Studying an Assamese literary text with another text from Assamese literature itself.

2. Studying other regional literature of India or World Literature, but its study is limited in its initial phase.

Mainly, the discussion of the explicit similarities and dissimilarities of two texts are the prevalent practicing method in Assamese literature.

In the recent time, the field of Comparative Literature in Assam saw, as a result of the practice of various critics, the emergence of a myriad of perspectives such as Post-colonialism, multilingualism, multiculturalism, sociology of literature, interdisciplinary angle of literature etc. through which it is studied and it paves the way for its enrichment with novel concepts. As Assam is a state of multilingualism and multiculturalism, hence, to make the study of Comparative literature inclusive, it should include the abovementioned perspectives.

There are mainly two reasons behind the limitation of the development of Comparative Literature in Assam and these are (Bora Tanuja, \& Nath, Dhrubajyoti, 2017): 1.Lack of translated works and 2. Absence of critics that is skillful in various languages. In current scenario, the comparative study between Assamese and Bengali literature is done in highest number. Moreover, in the available texts, the same topics and ideas are seen discussed. The comparative studies of Assamese literature with the literature of the other languages of India are not done extensively. In Gauhati and Dibrugarh University, in order to study Comparative Indian Literature, literatures of some Indian languages are selected and the languages are: Assamese, Bengali, Odia, and Hindi. The abovementioned four languages have some similarities among them and the literature of the Medieval and the Modern age of these four languages are included in the syllabus. In the multilingual society of Assam, there is an immense possibility for the development of Comparative Literature and in the light of the diverse knowledge of multilingual and multicultural society Comparative Literature can be studied. In this field, the regional languages of India should come forward for discussion and the tribal literature of Assam should also be included under the purview of Comparative literature. Although the study of the tribal literature from the standpoint of Comparative Literature is very rare, the amended syllabus of Dibrugarh University has included various perspectives and topics such multiculturalism, Cultural Studies, Sociology of Literature, film study, etc. in the study of Comparative Literature.

\section{CONCLUSION}

In Assam, the study of Comparative Literature and its curriculum has provided an immense contribution to the development of the intellectual world. Besides the inclusion of language-literature -culture in the study of Comparative Literature, the inclusion of Post-colonialism, multiculturalism, etc. has enriched the knowledge and thinking of the University students. But, there is a need to change with the passage of time and move along with practicality. Hence, as an academic subject, the scope of Comparative Literature should be broadened with time. The inclusion of interdisciplinary study with other mediums such as films, paintings, architecture, plays, etc. will make the curriculum more interesting. Moreover, there is a possibility of the development of comparative study among the literature written in Assamese reflecting the lives and cultures of various ethnic and tribal communities. The pattern of studying Comparative Literature in Assam should be of four phases and these are:

1. A comparative study among the biographical literature, written in Assamese, of various communities.

2. Comparative study between the literature of the Assamese language and the literature produced in the languages of various communities.

3. Comparative study between the Assamese literature and literature of Sanskrit and the other regional languages of India.

4. Comparative study between the Assamese literature and World Literature.

Another significant point is that in order to develop Comparative Literature, the act of giving emphasis on translation is of utmost importance. At the end of the study, it can be said that there are various fields in Assam for the study and practice of Comparative Literature and it gives a picture of immense possibilities for the development of the subject. Apart from strengthening the unity in multilingual and multicultural Assamese society, Comparative Literature can contribute towards the development of unity at the national level. The Comparative Study of Assamese language and literature with the literature of the regional languages of India can pave the way for bringing out the cultural relationship and unity of Assam with the other places of India.

\section{REFERENCE}

1. Ayer, N.E. Biswanath (2003), Anubad Kala, Prabhat Prakashan, New Delhi, Sanskaran

2. Bezborah, N. Mahanta (2009), Tulanamulak Sahitya _ Ek Gatishil Anushashan, Neog, Bibha Dutta, \& Handique Nivedita

3. B., Sahityar Swad-Baicitra, Assam (India), Kiran Prakashan

4. Bezborah, N. Mahanta (1999), Tulanamulak Bharitya Sahitya, Dibrugarh, Assam, Banalata

5. Publication

6. Bezborah, N. Mahanta (2019), Asamat Tulamulak Sahitya Sathik Dixe Aagbahisene? In Anuradha Sarmah Pujari (ed.),

7. Satsori, September, p.34-38 
8. Bora, Tanuja, \& Nath, Dhrubajyoti (2017). Comparative Literature in Assam: History and Practice, In Nath, Dhrubajyoti,

9. Tulanamulak Sahitya - Patabhumikat Asom (pp 121-136), Assam (India): Purbanchal Prakash

10. Buzarboruah, Pallavi Deka, (2008). Assamese Literature and Rabindra Philosophy, Assamese Literature:

11. Characteristics and Context, pp.12-17

12. Buzarboruah, Pallavi Deka, (2014). Comparative Indian Literature: an approach to a School, International

13. Journal of Humanities and Social Science Invention, pp.54-64

14. Buzarboruah, Pallavi Deka (2017). School of Comparative Literature: History and Present, In Nath, Dhrubajyoti (ed.),

15. Tulanamulak Sahitya - Patabhumikat Asom (pp 32-65), Assam (India): Purbanchal Prakash

16. Buzarboruah, Pallavi Deka (2018), Rabindranath Romanticism and Assamese Romantic Poetry, Gariokhi, September,

17. Assam

18. Buzarboruah, Pallavi Deka, (2013), Tulanamulak Sahityatattwa, Dibrugarh-1, Assam, Banalata, Publication.

19. Fokkema, W. Dollwe (1987), Issue in General \& Comparative Literature, Papyrus 2 Ganendra Mitra Lane, Calcutta

20. Harris, M., Karper, E., Stacks, G., Hoffman, D., DeNiro, R., Cruz, P., et al. (2001). Writing labs and the

21. hollywood connection. Journal of Film Writing, 44(3), 213-245

22. Hazarika, Karabi Deka (2003), Tulanamulak Sahitya Aru Anubad Kala, Banalata, Dibrugarh

23. Hazarika, Karabi Deka \& Buzarboruah, Pallavi Deka (2008), Tulanamulak Sahitya : Bikash Aru Bibortan, Assamese

24. Department, Dibrugarh University

25. Sharma, Jageswar (1977), Tulanamulak Sahitya, In Bhuyan, Jogendra Narayan (ed.), Assam Sahitya Sbha Patrika, p. 1-4

26. Kataki, Prafulla, (2012) Tulanamulak Sahitya aru Anubad Bisar, Guwahati, Panbazar, Jyoti Prakashan, Assam

27. Nath, Dhrubajyoti (2017), Tulanamulak Sahitya - Patabhumikat Asom, Assam (India) : Purbanchal Prakash

28. Saikia, Samutjal (2018), Assamot 'Tulanamulak Sahity'r Etihas Aru Jageswar Sharma, In Pujari, Anuradha Sarmah (ed.),

29. Satsori, December, p.8-9

30. Panikar, K. Ayyappa (1992), An Indian Apparoch, Spotlight on Comparative Indian Literature, Papyrus, Calcutta

31. Remark, Henry, H. (1961), Comparative Literature. Carbondal Southern Illinois University Press

32. Saikia, Nagen (2011), Sahitya-Badabaicitra, Dibrugarh, Assam (India), Kaustubh Prakashan 